\title{
INOVASI MODEL PEMBELAJARAN JARAK JAUH PROGRAM KESETARAAN PAKET C DI MASA PANDEMI COVID-19
}

\author{
Musyafa Ali ${ }^{1}$, Cesilia Prawening ${ }^{2}, \&$ Mukhamad Hamid Samiaji ${ }^{3}$ \\ email: musyafaali176@gmail.com¹, cesiliaprawening@gmail.com², \\ mukhamadhamid@gmail.com ${ }^{3}$ \\ Magister Pendidikan Islam Anak Usia Dini, UIN Sunan Kalijaga Yogyakarta \\ Jalan Laksda Adisucipto, Papringan, Caturtunggal, Depok, Sleman, \\ Daerah Istimewa Yogyakarta 55281, Indonesia
}

\begin{abstract}
Abstrak: Pandemi COVID-19 telah menghambat proses belajar dan pembelajaran baik pendidikan formal maupun pendidikan non formal seperti pada program kesetaraan Paket $C$. Guru atau tutor dituntut untuk dapat menghadirkan inovasi pembelajaran yang efektif. Pembelajaran jarak jauh dapat menjadi salah satu alternatif yang dapat diterapkan. Artikel ini bertujuan untuk mendeskripsikan inovasi model pembelajaran jarak jauh pada Program Kesetaraan di wilayah Purwokerto Selatan pada masa pandemik COVID-19. Jenis penelitian ini adalah penelitian kualitatif dengan metode etnografi. Pengumpulan data menggunakan tiga teknik yakni; melakukan observasi, wawancara, dan studi dokumen. Setelah data diperoleh kemudian peneliti melakukan analisis, adapun teknik analisis yang digunakan yakni; mereduksi, analisis dan penarikan kesimpulan. Hasil penelitian ini menunjukkan bahwa terdapat tiga metode pembelajaran yakni daring (live book, kuis, recording materi), luring (proyek karya), dan kombinasi (group observation or self-observation, rekaman materi, diskusi, investigasi dan webinar, dan apresiasi belajar). Ketiga metode pembelajaran ini merupakan modifikasi sekaligus adaptasi pembelajaran jarak jauh di masa pandemi COVID-19.
\end{abstract}

Kata-kata Kunci: inovasi, model pembelajaran jarak jauh, pandemi COVID-19, program kesetaraan paket c

\section{DISTANCE LEARNING MODEL INNOVATION OF PACKAGE C EQUALITY PROGRAM DURING COVID-19 PANDEMIC}

\begin{abstract}
The COVID-19 pandemic has hampered the learning and its process at all levels of education ranging from early childhood education to college. In addition to formal education, non-formal education such as the Package C Equality Program has also undergone drastic changes in the teaching and learning process. From that problem teachers or tutors are required to be able to present effective learning innovations. Distance learning can be one of the applicable alternatives. This article aims to describe the innovation of distance learning models in the Equality Program in the South Purwokerto region during the COVID-19 pandemic. This study is a field research with a qualitative approach. Data was collected using three techniques, namely; observations, interviews and document studies. The data then analysed based on these steps; reduction, analysis and withdrawal of conclusions. The results of this study show that there are three methods of learning namely online (live book, quiz, recording material), offline (project work), and combination (group observation or self-observation, recording material, discussion, investigation and webinar, and appreciation of learning). These three learning methods are both modifications and adaptations of distance learning during the COVID-19 pandemic.
\end{abstract}

Keywords: innovation, distance learning model, equality program package c, COVID-19 pandemic 


\section{PENDAHULUAN}

Penyebaran COVID-19 yang semakin meluas telah mengubah sistem pendidikan di Indonesia. Hal ini menjadi tantangan tersendiri bagi lembaga dan program pendidikan. Beberapa kendala yang timbul dalam pelaksanaan Pembelajaran Jarak Jauh (PJJ) di antaranya kesulitan guru dalam mengelola PJJ dan masih terfokus dalam penuntasan kurikulum. Sementara itu, tidak semua orang tua mampu mendampingi anak-anak belajar di rumah dengan optimal karena harus bekerja ataupun kemampuan sebagai pendamping belajar anak. Peserta didik juga mengalami kesulitan berkonsentrasi belajar dari rumah serta meningkatnya rasa jenuh yang berpotensi menimbulkan gangguan pada kesehatan jiwa.

Dalam menghadapi tantangan ini pemerintah telah berupaya untuk membatasi ruang gerak sosial (sosial distancing), mensosialisasikan pola hidup bersih dan sehat dengan menganjurkan masyarakat untuk menggunakan masker saat bepergian, serta rajin cuci tangan (Sadikin et al., 2020).

Mempertimbangkan kebutuhan pembelajaran, berbagai masukan dari para ahli dan organisasi serta mempertimbangkan evaluasi implementasi Surat Keputusan Bersama Empat Menteri, Pemerintah melakukan penyesuaian terkait pelaksanaan pembelajaran di zona selain merah dan oranye, yakni di zona kuning dan hijau, untuk dapat melaksanakan pembelajaran tatap muka dengan penerapan protokol kesehatan yang sangat ketat.

Prioritas utama pemerintah adalah untuk mengutamakan kesehatan dan keselamatan peserta didik, pendidik, tenaga kependidikan, keluarga, dan masyarakat secara umum, serta mempertimbangkan tumbuh kembang peserta didik dan kondisi psikososial dalam upaya pemenuhan layanan pendidikan selama pandemi COVID-19

Pembelajaran jarak jauh dapat dimaknai sebagai kegiatan pembelajaran yang tidak mengenal batas ruang dan waktu, mengondisikan kemandirian belajar peserta didik, dan menerapkan metode atau cara tertentu dalam pembelajaran (Kör et al., 2014) (Isman, 2017) (Iskenderoglu et al., 2012). Pembelajaran jarak jauh ini bersifat fleksibel karena pembelajaran dapat dilakukan di mana saja dan kapan saja, pendidik juga memiliki kebebasan memberikan akses referensi pada peserta didik perihal materi yang hendak disampaikan. Proses pembelajaran demikian dapat meningkatkan kualitas dan menunjang kegiatan pembelajaran (Pardede, 2011) (Yaniawati, 2013) (Lee et al., 2019).
Akan tetapi, dalam penerapan model pembelajaran jarak jauh tidak sedikit kendala atau problem yang harus dihadapi (Semradova \& Hubackova, 2016). Terlebih pada masa pandemi COVID-19 ini, permasalahan yang dihadapi adalah tidak semua peserta didik memiliki ponsel yang mendukung untuk belajar, sinyal yang sulit dijangkau atau ketidakmampuan peserta untuk membeli kuota data, dan kekurangcakapan pendidik dalam penyesuaian pembelajaran online menjadi hambatan yang cukup besar dalam mewujudkan tujuan pembelajaran yang diharapkan (Dursun et al., 2013), (Jaya, 2017), (Ahmad, 2020).

Proses pembelajaran yang efektif dan kondusif di masa pandemik COVID-19 menjadi sulit diterapkan. Hal ini dikarenakan pendidik dan peserta didik sebagai pemeran utama dalam pembelajaran harus menghadapi berbagai persoalan baru yang sebelumnya belum ada. Hal ini membuat seorang guru harus berpikir keras untuk menciptakan inovasi-inovasi baru dalam proses pembelajaran, khususnya model pembelajaran. Sebab dengan munculnya COVID-19 telah memberikan dampak cukup besar terhadap peserta didik seperti menurunnya minat belajar, banyaknya beban tugas yang diberikan pendidik, pembelajaran yang monoton menjadikan peserta didik cepat bosan, sehingga pembelajaran kurang efektif dan efisien.

Program Kesetaraan Paket C Wadas Kelir Karagklesem Purwokerto Selatan sebagai salah satu lembaga pendidikan nonformal yang bergerak di bidang pendidikan setara SMA telah melakukan berbagai inovasi model pembelajaran. Adapun model pembelajaran yang diimplementasikan oleh Paket $\mathrm{C}$ Wadas Kelir selama pandemi ini yakni luring, daring, dan kombinasi.

Menurut Nur Hafidz, seorang tutor pada Paket C Wadas Kelir, inovasi pembelajaran penting untuk dilakukan guna menghadirkan model pembelajaran yang menakjubkan dan menyenangkan. Terlebih di masa pandemi, guru juga dituntut untuk dapat mengimplementasikan model pembelajaran yang bebas COVID-19 dan mengkondisikan semangat belajar anak selama di rumah. Bukan hanya sebatas itu, guru juga dituntut agar tujuan pembelajaran dapat diwujudkan sesuai harapan. Tujuan ini tentu dapat terwujud dengan model pembelajaran yang tepat.

Kajian penelitian ini dikuatkan dengan penelitian Ahmad (2020), bahwa perlu adanya alternatif model pembelajaran yang mendukung proses pembelajaran jarak jauh secara baik dan efektif. Temuan selanjutnya 
yang menguatkan penelitian ini adalah penelitian Atsani bahwa sistem pembelajaran yang bisanya dilakukan tatap muka kini kondisi menghendaki untuk melakukan pembelajaran secara online baik menggunakan laptop maupun via WhatsApp, Zoom, ataupun media lainnya sebagai media pembelajaran (Atsani, 2020). Dari beberapa penelitan yang ada, maka penting bagi peneliti untuk mengkaji penelitian tentang inovasi model pembelajaran Paket $C$ yang diterapkan di Paket C Wadas Kelir selama pandemi.

Adapun tujuan penelitian ini adalah untuk mengeksplorasi bagaimana inovasi model pembelajaran yang diterapkan di Program Kesetaraan Paket C Wadas Kelir. Penelitian ini dapat dimanfaatkan sebagai rujukan atau role model pembelajaran di paket $\mathrm{C}$ atau setara SMA lainnya.

\section{METODE PENELITIAN}

Pendekatan kualitatif sebagai pendekatan yang digunakan dalam penelitian ini, dikarenakan penelitian dilakukan pada latar yang alamiah, penelitian yang harus alami tanpa ada penambahanpenambahan, sehingga data yang diperoleh sahih adanya dalam penulisan ini. Penelitian kualitatif, diartikan sebagai penelitan yang menggunakan latar secara alamiah, dengan tujuan menafsirkan suatu fenomena yang terjadi serta melakukannya dengan melibatkan beberapa metode (Moleong, 2017). Metode penelitian yang digunakan adalah etnografi, dimana peneliti adalah pengamat yang terlibat dalam kegiatan penelitian sebagai salah seorang tutor. Beberapa teknik pengumpulan data yang digunakan adalah wawancara, pengamatan, serta analisis dokumen. Wawancara dilakukan kepada para tutor dan warga belajar Pendidikan Kesetaraan Paket C Wadas Kelir yang terlibat dalam pembelajaran dan perancangan kurikulum. Selain itu peneliti juga melakukan pengamatan secara langsung terkait dengan kegiatan pembelajaran yang dilakukan selama pandemik.

Penelitian ini dilakukan di Pendidikan Kesetaraan Paket C Wadas Kelir, yang berada di bawah naungan PKBM Rumah Kreatif Wadas Kelir Purwokerto Selatan, Kabupaten Banyumas, Provinsi Jawa Tengah. Penelitian dilakukan pada Program Kesetaraan Rumah Kreatif Wadas Kelir yang merupakan salah satu lembaga pendidikan nonformal yang terus aktif belajar dengan melakukan berbagai terobosan pembelajaran yang inovatif dengan menyesuaikan situasi dan kondisi saat ini.

Dalam pengkajiannya, penulis melakukan tiga teknik pengumpulan data di antaranya: pertama; (1) studi dokumentasi, yakni metode dalam mencari dan menemukan data terkait dengan fokus penelitian seperti catatan, buku, transkip, presensi, majalah, surat kabar, prasasti, notulen, buku agenda, dan lain sebagainya. Metode dokumentasi dilakukan untuk melengkapi data yang didapatkan dari wawancara dan observasi (Arikunto, 2013). Peneliti menggali data-data terkait jurnal pembelajaran para tutor dan buku kurikulum sekolah Kejar Paket C Wadas Kelir (2) Observasi partisipatif yakni, terlibatnya peneliti dalam menyaksikan proses perencanaan, pelaksanaan, dan evaluasi pada kegiatan pembelajaran jarak jauh Kesetaraan Paket B dan C Rumah Kreatif Wadas Kelir. Peneliti turut menyaksikan kegiatan evaluasi yang dilakukan oleh para tutor dan warga belajar, selain itu peneliti turut serta berpartisipasi dalam melakukan evaluasi. (3) Wawancara mendalam, yakni teknik mengumpulkan data yang didapatkan langsung dari sumber informasi. Menurut Mantja (Harsono, 2008) wawancara mendalam dimaksudkan percakapan untuk memperoleh informasi etnografi secara terarah. Pada teknik ini, peneliti langsung melakukan kegiatan wawancara kepada tutor dan warga belajar baik secara daring maupun luring dengan bertemu langsung untuk melengkapi datadata yang diperoleh.

Prinsip dasar dalam melakukan analisis data yakni pada kronologi. Berikut tahap dalam menganalisis data yang peneliti lakukan secara tertata dengan menggunakan model Miles and Huberman yakni: 1) mereduksi data disini peneliti memilih hal-hal pokok yang terkait dengan penelitian berupa model pembelajaran jarak jauh pada program kesetaraan; 2) penyajian data dengan membuat uraian singkat berupa teks naratif, sehingga data yang relevan kemudian akan diperolah dan informasi dapat disesuaikan dengan tujuan dari penelitian yang dilakukan; dan 3) simpulan dan verifikasi. Kesimpulan yang didapatkan masih bersifat sementara, yang dapat berubah dikarenakan adanya data baru yang lebih akurat, sehingga harus mengubah kesimpulan penelitian. Perubahan data dapat terjadu dikarenakan adanya penyesuaian antara tutor dengan warga belajar dalam melakukan keefektifan model pembelajaran di Pendidikan Kesetaraan Kejar Paket C Wadas Kelir. 


\section{HASIL DAN PEMBAHASAN}

\section{Hasil Penelitian}

Berdasarkan hasil dokumentasi dan observasi di lapangan, peneliti memperoleh data terkait dengan Program Kesetaraan Paket C Wadas Kelir yang terletak Kelurahan Karangklesem Kecamatan Purwokerto Selatan Kabupaten Banyumas ini memiliki orientasi untuk mempersiapkan generasi yang unggul, literasi baik, tangguh, berakhlakul karimah dan bermanfaat bagi umat, memperkuat pondasi akidah dan akhlak, serta mengoptimalkan seluruh potensi siswa dengan bersinergi bersama orang tua siswa, masyarakat, dan pemerintah.

Program kesetaraan Paket C Wadas Kelir memiliki visi menciptakan generasi yang islami, cerdas, kreatif, dan berliterasi baik, serta memiliki misi mendidik peserta didik sebagai lulusan yang dapat menjunjung tinggi nilai Islam dan memiliki kepribadian mandiri serta menguasai teknologi terkini, terampil sesuai dengan minatnya, dan memiliki daya literasi yang tinggi, menyelenggarakan kegiatan dan proses pembelajaran yang mengintegrasikan pendidikan umum dan keislaman, dan menyelenggarakan program dengan menjalin sinergi lembaga, masyarakat dan pemerintah.

Tujuan utama program kesetaraan Paket C Rumah Kreatif Wadas Kelir adalah mempersiapkan generasi yang unggul, berliterasi baik, tangguh, berakhlakul karimah dan bermanfaat bagi umat. Memperkuat pondasi akidah dan akhlak. Mengoptimalkan seluruh potensi anak dengan bersinergi bersama orang tua siswa, masyarakat, dan pemerintah.

Adapun tutor pada Program Paket C PKBM Rumah Kreatif Wadas Kelir berjumlah 19 orang yang terdiri dari pamong belajar dan masyarakat pendidik yang mau dan mampu menjadi tutor dan memiliki kualifikasi pendidikan sesuai mata pelajaran, serta kompetensi pedagogik, kepribadian, sosial dan profesional.

Tabel 1.

Profil Tutor Lokasi Penelitian

\begin{tabular}{ccccc}
\hline No & L/P & Pen & Status & Karakteristik \\
\hline 1 & L & S3 & $\begin{array}{c}\text { Tutor \& } \\
\text { Penasihat }\end{array}$ & $\begin{array}{l}\text { Dosen, Tutor, Ketua } \\
\text { Yayasan Rumah } \\
\text { Kreatif Wadas Kelir } \\
\text { sekaligus Penasihat }\end{array}$ \\
\hline 2 & L & S1 & Tutor & $\begin{array}{l}\text { Tutor, sebelumnya } \\
\text { juga guru PAUD, dan } \\
\text { juga Relawan Rumah } \\
\end{array}$ \\
& & & & Kreatif Wadas Kelir \\
\hline
\end{tabular}

\begin{tabular}{|c|c|c|c|c|}
\hline No & L/P & Pen & Status & Karakteristik \\
\hline 3 & $P$ & S1 & Tutor & $\begin{array}{l}\text { Tutor, warga sekitar } \\
\text { Rumah Kreatif Wadas } \\
\text { Kelir }\end{array}$ \\
\hline 4 & $\mathrm{P}$ & S1 & Tutor & $\begin{array}{l}\text { Tutor sekaligus } \\
\text { lulusan Paket C SKB } \\
\text { Purwokerto }\end{array}$ \\
\hline 5 & $\mathrm{P}$ & S1 & Tutor & $\begin{array}{l}\text { Tutor, sekaligus } \\
\text { Relawan Rumah } \\
\text { Kreatif Wadas Kelir }\end{array}$ \\
\hline 6 & $P$ & S2 & Tutor & $\begin{array}{l}\text { Dosen, Tutor sekaligus } \\
\text { Relawan Rumah } \\
\text { Kreatif Wadas Kelir }\end{array}$ \\
\hline 7 & $p$ & S2 & Tutor & $\begin{array}{l}\text { Dosen, Tutor sekaligus } \\
\text { Relawan Rumah } \\
\text { Kreatif Wadas Kelir }\end{array}$ \\
\hline 8 & $P$ & S2 & Tutor & $\begin{array}{l}\text { Guru SKB Purwokerto } \\
\text { sekaligus Tutor dan } \\
\text { Relawan Rumah } \\
\text { Kreatif Wadas Kelir }\end{array}$ \\
\hline 9 & L & S1 & Tutor & $\begin{array}{l}\text { Tutor dan Relawan } \\
\text { Rumah Kreatif Wadas } \\
\text { Kelir }\end{array}$ \\
\hline 10 & $P$ & S2 & Tutor & $\begin{array}{l}\text { Dose n, Tutor } \\
\text { sekaligus Relawan } \\
\text { Rumah Kreatif Wadas } \\
\text { Kelir }\end{array}$ \\
\hline 11 & $P$ & S1 & Tutor & $\begin{array}{l}\text { Guru PAUD, Tutor } \\
\text { sekaligus Relawan } \\
\text { Rumah Kreatif Wadas } \\
\text { Kelir }\end{array}$ \\
\hline 12 & $P$ & S1 & Tutor & $\begin{array}{l}\text { Tutor sekaligus } \\
\text { Relawan Rumah } \\
\text { Kreatif Wadas Kelir }\end{array}$ \\
\hline 13 & $L$ & S1 & Tutor & $\begin{array}{l}\text { Ketua PKBM Rumah } \\
\text { Kreatif Wadas Kelir, } \\
\text { Tutor sekaligus } \\
\text { Relawan Rumah } \\
\text { Kreatif Wadas Kelir }\end{array}$ \\
\hline 14 & $L$ & S1 & Tutor & $\begin{array}{l}\text { Tutor sekaligus } \\
\text { Relawan Rumah } \\
\text { Kreatif Wadas Kelir }\end{array}$ \\
\hline 15 & L & S2 & Tutor & $\begin{array}{l}\text { Tutor sekaligus } \\
\text { Relawan Rumah } \\
\text { Kreatif Wadas Kelir }\end{array}$ \\
\hline 16 & $\mathrm{P}$ & S1 & Tutor & $\begin{array}{l}\text { Tutor sekaligus } \\
\text { Relawan Rumah } \\
\text { Kreatif Wadas Kelir }\end{array}$ \\
\hline 17 & $\mathrm{p}$ & S1 & Tutor & $\begin{array}{l}\text { Guru MI, Tutor } \\
\text { sekaligus Relawan } \\
\text { Rumah Kreatif Wadas } \\
\text { Kelir }\end{array}$ \\
\hline
\end{tabular}




\begin{tabular}{ccccc}
\hline No & L/P & Pen & Status & \multicolumn{1}{c}{ Karakteristik } \\
\hline 18 & P & S1 & Tutor & $\begin{array}{l}\text { Tutor sekaligus } \\
\text { Relawan Rumah } \\
\text { Kreatif Wadas Kelir }\end{array}$ \\
\hline 19 & P & S1 & Tutor & $\begin{array}{l}\text { Guru M I, Tutor } \\
\text { sekaligus Relawan } \\
\text { Rumah Kreatif Wadas } \\
\text { Kelir }\end{array}$ \\
\hline
\end{tabular}

Program Kesetaraan Paket C Wadas Kelir dikenal sebagai lembaga pendidikan nonformal yang terus aktif belajar dengan melakukan berbagai terobosan pembelajaran yang inovatif dan adaptif, seperti saat pandemi COVID-19 ini. Paket C Wadas Kelir berupaya untuk melakukan transformasi dan inovasi model pembelajaran yang semula berjalan secara konvensional menjadi virtual.

Dari hasil pengamatan di lapangan, sekaligus wawancara dengan salah seorang tutor di Program Kesetaraan Paket C Wadas Kelir, menyatakan bahwa inovasi model pembelajaran jarak jauh yang diterapkan oleh Program Kesetaraan Paket C Wadas Kelir di masa pandemi COVID-19 adalah sebagai berikut:

\section{Dalam Jaringan (daring) atau online}

Daring atau dalam jaringan (online). Semenjak COVID-19 menyebar di Indonesia, model pembelajaran ini adalah model pembelajaran yang diterapkan oleh sebagian besar lembaga pendidikan, mulai dari pendidikan anak usia dini hingga perguruan tinggi. Model pembelajaran daring yang dilaksanakan di Paket $C$ Wadaskelir hampir sama dengan model belajar daring pada umumnya, dimana tutor memberikan materi dan melakukan proses pembelajaran melalui aplikasi, adapun aplikasi pembelajaran yang dipakai selama pandemi yakni Whatsapp, Zoom, Live Book, recording materi, dan kuis.

Pertama, live book atau buku aktivitas yakni model pembelajaran pemberian tugas belajar secara mandiri melalui tugas, dimana warga paket sebelumnya telah diberi materi atau modul untuk dipelajari saat di rumah. Tugas yang diberikan oleh tutor berupa tugas terstruktur dan tugas non terstruktur. Tugas terstruktur ini diberikan dengan tujuan meningkatkan kemampuan warga paket untuk memahami suatu materi pelajaran. Tugas non terstruktur, tujuan dari pemberian tugas ini sebenarnya hampir sama dengan tugas terstruktur, hanya saja waktu yang diberikan oleh tutor pada warga paket lebih panjang, bisa dalam kurun waktu minggu, atau bulan. Tujuan dari model pembelajaran ini yakni memberikan kebebasan warga untuk belajar secara mandiri dengan materi yang telah diberikan dan memberikan kesempatan pada warga untuk memahami materi plejaran secara mandiri di rumah. Dampak dari penerapan model belajat ini yakni warga paket menjadi lebih madiri dalam melaksanakan kegiatan belajar, saat ada pembelajaran luring warga paket juga lebih bersemangat. Namun disisi lain saat model belajar ini tidak ada pengontrolan warga belajarpun akan merasakan kebosanan dan dapat berdampak pada rasa enggan untuk belajar. Oleh karena itu, saat tutor menerapkan metode ini maka tutor harus tetap memantau perkembangan dari warga paket meskipun via daring.

Kedua, recording atau rekaman, metode pembelajaran ini dapat digunakan oleh semua tutor dan semua mata pelajaran. Recording adalah model belajar dimana tutor merekam materi dapat berbentuk rekaman suara atau video. Tujuan dari model belajar ini yakni memberikan suasana belajar baru pada warga, sehingga saat belajar warga paket tidak hanya terfokus pada buku, melainkan juga dapat belajar menggunakan media visual atau melalui rekaman suara yang dibuat oleh tutor.

Media yang biasa digunakan oleh tutor dalam mengaplikasikan model pembelajaran ini yaitu Whatssap dan Youtube. Penerapan metode ini dapat digunakan sewaktu-waktu, misal saat tutor berhalangan mengajar saat itu, maka sebelum mengajar tutor dapat mengirim video atau rekaman kepada warga paket, sehingga saat jam belajar dimulai warga dapat melihat atau mendengar rekaman yang telah dibagi. Sebagai alat kontrol, biasanya tutor menyelipkan pertanyaan yang nantinya harus dijawab oleh warga paket, hal ini bertujuan agar warga paket benar-benar mendengarkan dan menyimak materi yang telah disampaikan. Saat pelaksanaan pembelajaran ini warga yang belum menguasai materi juga dapat meninggalkan komentar pada tutor untuk nantinya dapat dijelaskan dan diulas kembali oleh tutor pada pertemuan yang akan datang, atau dibahas di luar jam belajar. Di masa pandemi seperti saat ini model ini dapat dijadikan model belajar yang cukup efektif, selama tutor mampu melakukan inovasi dan memperbarui model ini. Selain tutor, warga paket juga dapat merasakan kemudahan dalam belajar, asalkan warga paket memiliki akses internet.

Ketiga, kuis yang merupakan proses menjawab pertanyaan dengan waktu yang terbatas atau telah ditentukan. Model pembelajaran dengan kuis, yakni model belajar pemberian soal 
pada peserta didik dan saat itu juga dijawab oleh warga. Tujuan pembelajaran ini untuk mengasah kecepatan dan ketepatan warga dalam menjawab sebuah soal yang diberikan oleh tutor selain itu model ini juga mengasah kemampuan warga atas pemahaman pembelajaran yang selama ini diajarkan oleh tutor.

Dalam pelaksanaannya pembelajaran model ini biasanya saat jam pembelajaran dimulai, tutor akan membagikan soal via Whatssap yang harus dijawab dan warga harus segara menjawab dalam waktu yang telah ditentukan, setelah waktu habis, maka tutor akan langsung menghapus soal dan melanjutkan soal yang lainnya, atau dilaksanakan dengan aplikasi Quizziz. Saat warga paket terlalu lama dalam menjawab dan waktu habis, maka warga tidak akan dapat menjawabnya dan dengan begitu skor yang didapatkan pun akan berkurang. Hal ini memicu warga untuk berpikir cepat dan tepat. Namun kelemahan menggunakan model belajar ini yakni terkadang peserta memilih jawaban yang salah atau mengarang, khususnya pada soal kategori sulit, dan saat diaplikasikan pada mata pelajaran yang lebih banyak berhitung, biasanya warga akan mengalami kesulitan, karena harus berpikir dan berhitung terlebih dahulu untuk mencari jawabannya.

Tujuan utama dari pembelajaran model ini adalah agar warga dapat belajar selama di rumah dan memutus mata rantai penularan COVID-19. Melalui pembelajaran daring ini peserta didik dikondisikan untuk dapat belajar secara mandiri. Adapun kendala umum yang dialami oleh warga paket adalah saat jaringan internet yang kurang memadai.

\section{Luar Jaringan (Luring)/Tatap Muka}

Pembelajaran luring atau pembelajaran luar jaringan merupakan model pembelajaran yang dilakukan secara langsung antara warga belajar dengan tutor. Tujuan dari model pembelajaran ni adalah memecahkan kebosanan warga selama belajar online dan di rumah, selain itu dengan adanya pembelajaran ini juga menjalin kedekatan antara tutor dan warga, khususnya warga belajar yang baru. Ada banyak keuntungan yang didapat dari model pembelajaran ini, selain yang sudah disebutkan tadi. Model ini juga menjadikan komunikasi dua arah lebih efektif, Pembelajaran secara luring, tutor memanfaatkan untuk menekankan materi yang sekiranya saat pembelajaran daring kurang dan melakukan kegiatan praktik pada kegiatan- kegiatan pembelajaran tertentu, seperti olahraga dan rekreasi, seni budaya, ketrampilan fungsional, prakarya dan mata pelajaran lainnya.

Model pembelajaran ini dilakukan dengan model 2-3, yakni model belajar tatap muka yang dilakukan secara bergilir yakni dengan cara mengadakan pertemuan dengan warga paket selama tiga hari di minggu pertama dan minggu ketiga dan dua hari di minggu ke dua dan keempat secara bergantian. Pertemuan dilakukan pada malam hari sesuai jam belajar, dengan model tutor yang mengajar secara bergantian, selama pandemi pemebelajaran dilakukan sesuai protokol kesehatan, yakni ketika warga paket datang mereka harus cuci tangan atau menggunakan handsanitizer, menggunakan masker selama belajar dan posisi duduk yang berjarak. Keuntungan dari penerapan model ini yakni pembelajaran lebih berkesan, pembelajaran lebih interaktif, terjalin kedekatan yang lebih dan terjadi komunikasi dua arah yang lebih efektif.

Adapun kegiatan belajar luring yang lainnya yakni model belajar proyek karya sebagai model belajar di mana warga paket belajar secara mandiri atau berkelompok diberi tugas untuk menghasilkan sebuah karya sesuai instruksi yang diberikan oleh tutor. Tujuan dari model pembelajaran ini adalah membekali warga paket dengan ketrampilan soft skill maupun hard skill. Inti dari model ini adalah pemberian kompetensi di bidang non akademik yang nantinya dapat digunakan oleh warga paket setelah selesai menempuh pendidikan. Selain itu model ini juga memberikan pengalaman langsung kepada warga setelah mendapatkan teori saat belajar. Tidak semua mata pelajaran menerapkan model proyek karya, hanya beberapa pelajaran yang menerapkan model ini seperti mata pelajaran prakarya, seni budaya, dan ketrampilan fungsional. Pelaksanaan proyek karya juga tidak selalu dilakukan di setiap pertemuan atau pembelajaran, model ini biasanya dipraktikkan pada tema-tema tertentu, akhir tema pembelajaran, akhir semester atau dijadikan sebagai bahan ujian praktik oleh tutor.

Saat pandemi model ini menjadi inovasi baru agar warga tidak merasa bosan akan model belajar yang monoton, dengan adanya tugas ini warga dapat menerapkan teori, dan mengekspresikannya dalam bentuk sebuah karya. Namun model ini juga memilki beberapa kelemahan yakni, di Paket C Wadaskelir sendiri terkadang ada warga yang merasa terbebani, karena mereka harus bekerja 
dan disisi lain harus mengerjakan tugas yang harus menghasilkan sebuah karya.

Salah satu kekhasan dari model pembelajaran proyek karya ini adalah kreativitas warga paket lebih berkembang. selain itu proyek karya juga menjadi salah satu kegiatan belajar yang hasil akhir belajar ini adalah terciptanya sebuah karya atau produk yang dihasilkan oleh warga paket, baik produk dengan nilai ekonomis ataupun nilai guna bagi kehidupan sehari-hari.

\section{Kombinasi}

Model belajar jarak jauh kombinasi yakni model belajar dengan menggabungkan metode daring dan luring. Adapun model belajar kombinasi yang dilakukan yakni: Group observation or self observation, diskusi, investigasi dan webinar, serta apresiasi belajar.

Pertama, observasi atau seringkali diartikan sebagai proses pengamatan. Group observation or self observation adalah proses observasi atau pengamatan secara langsung yang dilakukan oleh warga paket dalam rangka mengumpulkan data dan mengamati sebuah fenomena yang terjadi di lingkungannya. Dalam penerapannya, model pembelajaran ini diterapkan dalam rangka memberikan pemahaman pada warga paket akan fenomena-fenomena sosial yang terjadi di lingkungan sekitar rumah warga paket. Model ini diterapkan dalam model kelompok dan mandiri. Pembelajaran ini mengajarkan warga paket untuk belajar mengamati fenomena yang terjadi di lingkungan sekitar mereka, untuk kemudian warga juga melakukan proses pencatatan dan analisis dan hasil akhir berupa laporan, penemuan baru dan penemuan solusi. Pembelajaran model ini diaplikasikan di beberapa mata pelajaran, misal PPKN, Geografi dan lain-lain. Model ini diterapkan dan disesuaikan dengan tema pelajaran yang ada dan dilaksanakan dalam satu semester. Biasanya hanya dilakukan satu semester satu sampai dua kali. Dengan diterapkannya model belajar ini warga dapat mengamati secara langsung fenomena atau kejadian sosial yang ada di lingkungan sekitar dan dituangkan dalam bentuk tulisan atau laporan.

Kedua, diskusi adalah model belajar interaktif, di mana pembelajaran ini mengharuskan adanya interaksi antara tutor dan warga paket. Dalam diskusi ini biasanya antara tutor dan warga paket membahas tema yang ada dalam materi dan dikaitkan dengan fonomena atau kejadian yang sedang terjadi saat ini, misal dalam kajian agama yang dikaitkan dengan pandemi COVID-19, dengan keadaan sosial dan sebagainya. Model ini dilakukan saat pembelajaran tatap muka maupun daring. Saat pembelajaran luring atau langsung biasanya tutor akan memancing atau memberikan sebuah permasalahan terlebih dahulu kepada warga paket, untuk kemudian warga paket harus memberikan argumentasi dan memberikan solusi atau jalan keluar. Saat pembelajaran daring, pembelajaran ini dapat dilakukan melalui aplikasi Whatsapp, Google Meet, Zoom atau aplikasi lainnya. Dalam model belajar ini posisi tutor tidak menggurui, namun lebih berperan sebagai fasilitator, sehingga terjadi adanya interaksi dua arah dan pertukaran informasi antara warga dan tutor.

Diskusi yang dilakukan juga bertujuan untuk membuka dan menumbuhkan pola pikir kritis peserta didik, menciptakan kedekatan antara warga dan tutor, membantu berpikir kritis, mencari formulasi atas sebuah masalah, dan mengajarkan untuk berani berargumentasi serta berpendapat di muka umum. Umumnya saat model ini diterapkan warga paket akan mulai berpendapat sesuai dengan opini, hal yang dialami, apa yang dilihat dan sebagainya sebagai bahan argumentasinya. Selain itu juga warga paket akan berpikir terkait apa yang akan diungkapkan, bahkan warga akan mencari-cari informasi di internet. Namun di sisi lain bagi warga yang kurang mampu mengusai tema biasanya di awal akan mengalami kesulitan dalam mengungkapkan argumentasinya bahkan malu untuk berpendapat.

Ketiga, model belajar investigasi dan webinar adalah model belajar yang memadukan antara model observasi lapangan dengan seminar. Investigasi atau melakukan pengamatan lapangan, pada umumnya investigasi lebih ke bidang ekonomi, namun pada Paket $C$ Wadaskelir, investigasi lebih bersifat umum. Webinar merupakan kegiatan seminar yang dilakukan dalam jaringan atau online. Tujuan dari model belajar ini tidak jauh berbeda dengan model observasi, yakni memberi pengalaman langsung dan membandingkan antara teori dengan fenomena di lapangan, yang nantinya hasil dari investigasi diseminarkan di hadapan tutor dan warga paket yang lain. Model ini tidak hanya dilakukan oleh warga paket saja, namun dapat dilaksanakan oleh tutor dan juga kolaborasi tutor dan warga paket. Pelaksanaan model ini dilaksanakan pada akhir semester, dan dapat digunakan sebagai hasil evalusi belajar pula. Dalam pelaksanaannya tutor harus lebih aktif dalam 
membimbing warga paket dalam melaksanakan investigasi, sehingga lebih mudah dan tepat apabila dilakukan bersama antara tutor dan warga paket.

Apresisasi belajar adalah bentuk pemberian penghargaan atas kerja dan hasil belajar siswa. Apresiasi belajar yang dilakukan atau diberikan oleh tutor bukan hanya diberikan pada warga paket yang berprestasi, apresiasi juga bukan hanya dalam bentuk penghargaan akan hasil belajar. Apresiasi belajar yang ada di paket $\mathrm{C}$ diberikan ketika warga semangat mengumpulkan tugas, semangat belajar, keaktifan, apresiasi seni (pementasan seni) dan lain sebagainya. Tujuan dari pemberian apresiasi ini adalah untuk menghargai perjuangan dan usaha yang dilakukan oleh warga belajar, agar mereka juga lebih semangat dalam belajar. Kemudian saat ada yang mendapat apresiasi, maka teman yang lain juga akan menjadi terinspirasi sehingga memicu semangat bersaing dalam belajar. Selain itu dengan adanya pemberian apresiasi kompetisi belajar warga juga meningkat. Apresiasi yang diberikan oleh tutor pada warga tidak harus berupa materi, bisa juga pemberian bintang prestasi, poin, ataupun yang lainnya, yang nantinya poin akan dijumlahkan di akhir semester dan tutor akan menggantinya dengan bentuk apresisasi yang lain. Pemberian apresiasi dapat dilakukan oleh tutor sewaktu-waktu atau kapanpun, misal saat jam belajar, di akhir belajar, atau melihat kondisi-kondisi lain sebagai pemacu semangat warga. Dengan adanya pemberian apresiasi ini proses belajar juga menjadi lebih interaktif.

\section{Pembahasan}

Sebelum melakukan inovasi pembelajaran jarak jauh selama masa pandemi, beberapa hal yang dilakukan para tutor melakukan diantaranya adalah menentukan pendekatan pembelajaran yang menjadi cara yang dilakukan oleh tutor dalam melakukan kegiatan pembelajaran. Tujuannya untuk memudahkan tutor dan warga belajar dalam proses belajar. Pendekatan yang dilakukan pada program Paket C Rumah Kreatif Wadas Kelir meliputi pendekatan yang berorientasi kepada warga belajar, bahan ajar, model pengajaran dan seluruh kegiatan pendidikan selama masa pandemi COVID-19 dan pembelajaran jarak jauh.

Setelah menentukan pendekatan pembelajaran selama beberapa minggu pembelajaran jarak jauh, kemudian tutor mencoba merumuskan model pembelajaran. Adapun model yang digunakan yaitu model daring, luring dan kombinasi. Setelah model ditentukan kemudian tutor mencoba meramu metode yang yang digunakan dalam pembelajaran jarak jauh, dengan menciptakan metode belajar baru, seperti, live book, recording materi, kuis, diskusi, group observation or self observation, webinar dan apresiasi belajar.

Hambatan dan upaya yang dilakukan saat pembelajaran jarak jauh, baik oleh tutor, warga belajar dan dipaparkan pada bagian berikut ini.

Pertama, dari sisi tutor. Mereka sering terkendala oleh sinyal atau jaringan, respon warga belajar (warga belajar kurang aktif), warga belajar terlambat hadir mengikuti pembelajaran karena harus bekerja terlebih dahulu, dan keterlambatan warga dalam mengumpulkan tugas belajar.

Dari permasalahan-permasalahan yang dialami oleh tutor, mereka juga melakukan beberapa upaya dalam rangka menanggulangi hal-hal tersebut di antaranya, saat tutor terkendala oleh sinyal, biasanya tutor akan berusaha mencari solusi dengan cara tethering dengan rekan yang ada dengan tujuan agar pembelajaran dapat berjalan efektif. kemudian untuk mengatasi kurang aktifnya warga paket biasanya tutor langsung memberikan kuis pada warga paket, memberikan poin prestasi pada warga paket yang aktif, atau menunjuk satu persatu warga paket untuk menjawab atau berkomentar atas materi yang disampaikan oleh tutor. Dalam menanggulangi masalah warga paket yang terlambat, biasanya tutor akan mengabsen terlebih dahulu warga belajar 10 menit sebelum pembelajaran dimulai. Tujuannya adalah untuk mengontrol, kemudian bagi warga yang sedang bekerja bisa izin terlebih dahulu untuk masuk terlambat, kemudian bagi warga belajar yang terlambat tutor tidak memberi sanksi atau hukuman apapun, tutor memberikan toleransi keterlambatan warga paket ketika harus masuk terlambat karena harus bekerja, namun tutor biasanya akan memberikan pertanyaan bagi warga paket di pertemuan yang akan datang sebagai bahan ulasan dan evaluasi atas materi yang telah disampaikan, dan memastikan warga belajar yang telat minggu lalu telah belajar.

Dalam pengumpulan tugas masing-masing tutor memiliki kebijakan masing-masing, namun usaha yang dilakukan oleh tutor untuk meminimalkan keterlambatan warga belajar dalam mengumpulkan tugas warga paket yakni dengan selalu mengingatkan, memberikan tugas yang harus dijawab oleh warga saat itu juga (semacam kuis), dan tidak memberikan beban tugas yang terlalu banyak.

Kemudian dalam melaksanakan kegiatan pembelajaran secara luring atau luar jaringan, untuk tutor sendiri tidak mengalami kendala apapun, karena 
tutor dapat melaksanakan kegiatan secara langsung dan juga pembelajaran juga dirasa lebih efektif.

Untuk pembelajaran model gabungan sendiri ada beberapa kendala yang dirasakan oleh tutor di antaranya yakni, karena warga paket umumnya sudah berkeluarga dan bekerja, maka biasanya warga paket lebih pasif. Saat melaksanakan pembelajaran gabungan seperti webinar biasanya sebelum dimulai, tutor memberikan catatan atau pemahaman terkait apa yang harus disampaikan oleh warga. Selain itu, tutor juga memberi tugas untuk dipelajari terlebih dahulu terkait apa yang akan disampaikan saat webinar.

Tantangan yang dihadapi oleh tutor dalam melaksanakan pembelajaran daring ini, tutor harus mempersiapkan materi jauh-jauh hari terutama yang menggunakan recording yang berupa video, selain itu saat menggunakan pembelajaran luring, tutor dituntut kreatif dan aktif agar warga belajar tidak mudah bosan dan dapat memahami materi. Dalam menyampaikan materi harus terstruktur dan rinci, menggunakan bahasa yang mudah dipahami dan sederhana. Materi yang disampaikan juga perlu dipecah bagian per bagian agar mudah dimengerti oleh warga paket.

Kedua, bagi warga paket, kendala yang dialami selama melaksanakan kegiatan belajar jarak jauh secara daring adalah terkendala sinyal, materi yang sulit dipahami, waktu yang bentrok antara jam belajar dan jam kerja, dan tugas yang banyak.

Dalam menangani susah sinyal, warga belajar akan tetap ikut belajar meskipun terlambat, yang penting bisa mengisi daftar hadir. Selain itu, meskipun telat dalam menjawab kuis dan tidak dapat poin juga mereka tetap berusaha menjawab. Dalam mengatasi materi yang sulit biasanya warga saling tanya ke temannya, namun kadang juga kalau tidak memahami, mereka tetap berkomitmen untuk membaca dan menyelesaikan materinya. Selain itu, mereka biasanya juga meminta tutor untuk menjelaskan melalui voice note.

Sementara, untuk menangani bentrok jam kerja dan jam belajar biasanya mereka tetap ikut belajar meskipun terlambat, ataupun mereka tetap belajar selama kegiatan dilaksanakan daring. Mereka juga meskipun harus sambil bekerja tetap mengikuti kelas, hanya saja kalau ada sesi tanya jawab, biasanya kurang aktif tapi tetap mengikuti. Terkait tugas yang banyak, mereka sudah memiliki strategi, karena biasanya tugas banyak di awal periode atau bulan pertama belajar. Namun jika telah berada di pertemuan ke 4 atau 5 sudah berkurang. Jika sedang banyak tugas, mereka tetap mengerjakan hanya sebisanya saja.

Untuk kegiatan pembelajaran luring sendiri, tidak pernah ada kendala, kecuali kalau hujan, biasanya tutor menggantinya dengan online. Saat belajar luring, mereka merasa lebih enak, lebih jelas, kalau tidak bisa, bisa langsung bertanya dan materi lebih mudah dipahami. Dan untuk belajar gabungan biasanya lebih banyak tutor yang menyampaikan dari pada mereka.

Beberapa warga paket juga mengungkapkan ada beberapa kelebihan dan kekurangan yang dialami selama belajar jarak jauh. Kelebihannya, belajar bisa sambil santai fleksibel, tidak perlu pergi ke sekolah, cukup di rumah, dan lain sebagainya. Hanya saja pembelajaran jarak jauh juga memiliki kelemahan di antaranya sulit memahami materi, kadang sinyal susah, kadang banyak tugas.

Jadi, faktor-faktor yang memengaruhi kualitas pembelajaran selama jarak jauh di antaranya yakni: (1) kreativitas tutor dalam melaksanakan pembelajaran; (2) komunikasi dan koordinasi tutor yang dilaksanakan secara intens, baik koordinasi dan komunikasi secara online maupun offline; (3) semangat tutor dan warga paket dalam melaksanakan pembelajaran dan belajar; (4) keterbukaan antara tutor dan warga paket, yakni tutor menanyakan kendala apa yang dirasakan oleh warga paket selama belajar, hal ini dijadikan bahan evaluasi bagi tutor; (5) evaluasi yang dilaksanakan secara rutin baik evaluasi tutor maupun evaluasi bersama warga paket.

\section{PENUTUP}

Dari hasil dan pembahasan penelitian ini maka dapat disimpulkan inovasi model pembelajaran jarak jauh di masa pandemi adalah sebuah konsep pembaharuan model pembelajaran dari yang sebelumnya sudah ada dan dikembangkan atau dilakukan dengan metode yang berbeda, guna melakukan pembelajaran jarak jauh agar hasil belajar tetap efektif. Inovasi yang dilakukan oleh Paket C Wadas Kelir, yaitu dengan melakukan tiga model pembelajaran, yakni; luring, daring, dan kombinasi. Dimana ketiga model tersebut di ramu dengan menciptakan metode belajar baru, seperti, live book, recording materi, kuis, diskusi, group observation or self observation, webinar dan apresiasi belajar. Adapun dalam penerapan inovasi pembelajaran jarak jauh yang telah dirumuskan oleh tutor dalam rangka menjaga semangat belajar dan mengefektifkan pembelajaran warga, tutor dan warga paket saling berkontribusi dalam memberikan inovasi- 
inovasi pembelajaran selama masa pandemi. Dalam penerapan inovasi pembelajaran jarak jauh tutor lebih bergerak aktif dan terus memberikan kontribusi inovasi serta kreasi demi mewujudkan pembelajaran yang lebih baik, sehingga warga paket tidak merasa jenuh dan bosan selama belajar di masa pandemi. Kemudian kontribusi yang diberikan warga belajar adalah evaluasi sekaligus masukan untuk inovasi-inovasi pembelajaran yang dapat dilakukan oleh tutor dalam melaksanakan pembelajaran.

\section{DAFTAR PUSTAKA}

Ahmad, I. F. (2020). Alternative Assessment in Distance Learning in Emergencies Spread of Corona Virus Disease (COVID-19). Jurnal Pedagogik, 07 (01), 195-222. DOI: 10.33650/ pjp.v7i1.1136

Arikunto, S. (2013). Prosedur Penelitian Suatu Pendekatan Praktik. Rineka Cipta.

Atsani, K. L. G. M. Z. (2020). Transformasi Media Pembelajaran Pada Masa Pandemi COVID-19. Al-Hikmah: Jurnal Studi Islam, 1(1), 8293. DOI: 10. 21009/jtp.v22i1.15286

Dursun, T., Oskaybaş, K., \& Gökmen, C. (2013). The Quality of Service Of The Distance Education. Procedia - Social and Behavioral Sciences, 103, 1133-1151. DOI: 10.1016/j. sbspro.2013.10.441

Harsono. (2008). Konsep Dasar Mikro, Meso, dan Makro Pembiayaan Pendidikan. Surayajaya Press.

Iskenderoglu, M., Iskenderoglu, T. A., \& Palanci, M. (2012). Opinion of Teaching Staff in Distance Education Systems, Regarding the Assessment and Evaluation Process. Procedia - Social and Behavioral Sciences, 46 (March), 4661-4665. DOI: 10.1016/j.sbspro.2012.06.314

Isman, M. (2017). Pembelajaran Moda dalam Jaringan (Moda Daring). Proceedings. Progressive and Fun Education International Conference, 586-588. Retrieved from https://publikasiilmiah. ums.ac.id/handle/11617/7868

Jaya, H. N. (2017). Keterampilan Dasar Guru untuk Menciptakan Suasana Belajar yang Menyenangkan. Jurnal Pendidikan Dan IImu Pengetahuan, 17(1), 23-35. Retrieved from http://103.114.35.30/index.php/didaktis/article/ view/1555/1275

Kör, H., Aksoy, H., \& Erbay, H. (2014). Comparison of the Proficiency Level of the Course Materials (Animations, Videos, Simulations, E-books) Used in Distance Education. Procedia - Social and Behavioral Sciences, 141, 854-860. DOI: 10.1016/j.sbspro.2014.05.150

Lee, K., Choi, H., \& Cho, Y. H. (2019). Becoming a competen self: A developmental process of adult distance learning. Internet and Higher Education, 41(October 2017), 25-33. DOI: 10.1016/j.iheduc.2018.12.001

Moleong, L. J. (2017). Metode Penelitian Kualitatif. PT Remaja Rosdakarya Offsite.

Pardede, T. (2011). Pemanfaatan e-learning sebagai media pembelajaran pada pendidikan tinggi jarak jauh. Seminar Nasional FMIPA UT 2011, 1, 55-60. Retrieved from http://repository.ut.ac. $\mathrm{id} / 2511 /$

Sadikin, A., Johari, A., \& Suryani, L. (2020). Pengembangan multimedia interaktif biologi berbasis website dalam menghadapi revolusi industri 4.0. Edubiotik: Jurnal Pendidikan, Biologi Dan Terapan, 5 (01), 18-28. DOI: 10.33503/ebio.v5i01.644

Semradova, I., \& Hubackova, S. (2016). Teacher Responsibility in Distance Education. Procedia Social and Behavioral Sciences, 217, 544-550. DOI: 10.1016/j.sbspro.2016.02.042

Yaniawati, R. P. (2013). E-Learning to Improve Higher Order Thinking Skills (HOTS) of Students. Journal of Education and Learning (EduLearn), 7 (2), 109. DOI: 10.11591/edulearn.v7i2.225 